\title{
The effectiveness of sensory processing training on some neuropsychology skills of students with visual impairment
}

\author{
Salar Faramarzi ${ }^{1 *}$ iD, Mohammad Ashori², Golnesa Shoaei ${ }^{3}$ \\ 1. Associate Professor, Department of Psychology and Education of Children with Special Needs,Faculty of Education and Psychology, \\ University of Isfahan, Isfahan, Iran \\ 2. Assistant Professor, Department of Psychology and Education of Children with Special Needs, Faculty of Education and Psychology, \\ University of Isfahan, Isfahan, Iran \\ 3. MA in General Psychology, Department of Psychology, Isfahan (Khorasgan) Branch, Islamic Azad University, Isfahan, Iran
}

Recieved: 29 Oct. 2017

Revised: 18 Sep. 2018

Accepted: 27 Sep. 2018

Keywords

Sensory processing

Neuropsychology

Visual impairment

Corresponding author

Salar Faramarzi, Associate Professor, Department of Psychology and Education of Children with Special Needs, Faculty of Education and Psychology, University of Isfahan, Isfahan, Iran

Email: S.faramarzi@edu.ui.ac.ir

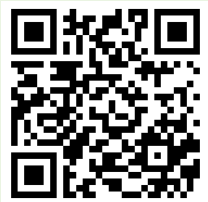

\section{Abstract}

Introduction: Visual impairment affects all aspect of individual's life and its family, as well as cognitive and neuropsychological skills; however, the use of sensory processing training has been associated with desirable outcomes. The present research aimed to investigate of the effectiveness of sensory processing training on some neuropsychology skills of attention, working memory and executive functions of students with visual impairment. Methods: The present study was a single-subject study with the base line, intervention and follow up design. The participants included elementary students with visual impairment in Isfahan city, among whom 5 students who had problems in neuropsychological skills and with visual impairment were selected using convenient sampling method. In total, 10 sessions, three sessions per week of 45 -minutes sensory processing training were administrated to sample group. The instrument used in the present research was Connors neuropsychological questionnaire. The obtained data were analyzed using visual analysis.

Results: The results showed that sensory processing training led to improve attention, working memory and executive functioning neuropsychology skills of students with visual impairment.

Conclusion: Consequently, with paying attention to the obtained results of the present research, recommend that along with the other educational and rehabilitation methods for children with visual impairment, applied sensory processing training can be taken into account. 


\title{
بررسى تأثير آموزش يردازش حسى بر برخى مهارتهاى عصب روانشناختى دانش آموزان با آسيب بينايى
}

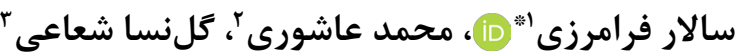

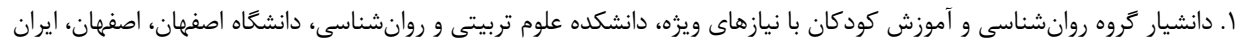

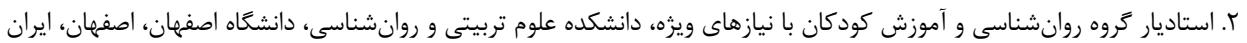

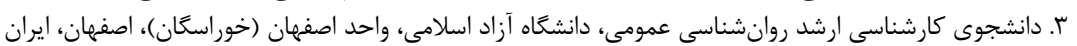

مقلدمه: آسيب بينايى تمام جنبههاى زندكى فرد از جمله مهارت هاى شناختى و عصب روانشناختى وى را تحت تأثير قرار مىدهد، اين در حالى كه استفاده از برنامه آموزش ڤبردازش حسى با نتايج مطلوبى همراه بوده است. يزوهش حاضر با هدف بررسى تأثير آموزش يردازش حسى بر برخى از مهارتهاى عصب روانشناختى توجه، حافظه و كاركردهاى اجرايى

$$
\text { دانشآموزان با آسيب بينايى انجام شد. }
$$

روش كار: يُوهش حاضر از نوع تك آزمودنى و با طح خط يايه، مداخله و پِيكيرى بود. جامعه آمارى اين يزوهش شامل كليه دانش آموزان دبستانى با آسيب بينايى شهر اصفهان تشكيل بود كه از ميان آنها ه دانشآموز كه در زمينه مهارتهاى عصب روانشناختى داراى مشكل بودند با استفاده از روش نمونهكيرى در دسترس وارد مطالعه شدند. مداخله آموزشى يردازش حسى بر روى كروه نمونه در ده جلسه به صورت هفتهاى سه جلسه و هر جلسه لهأ دقيقه انجام كرفت. ابزار مورد استفاده در اين يزوهش، يرسشنامه عصب روانشناختى Connors بود. دادههاى به دست آمده به شيوه تحليل ديدارى مورد تجزيه و تحليل قرار گرفت. يافته ها: نتايج نشان داد كه آموزش ثردازش حسى به طور قابل توجهى سبب بهبود مهارتهاى عصب روانشناختى توجه، حافظه و كاركردهاى اجرايى دانشآموزان دبستانى با آسيب بينايى مىشود. نتيجه كَيرى: با توجه به نتايج به دست آمده در يزوهش حاضر، پِيشنهاد مىشود كه در كنار ساير روشهاى آموزشى و توانبخشى كودكان با آسيب بينايى، روش آموزش يردازش حسى نيز به كار برده شود.

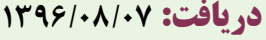
اصلاح نهايى:

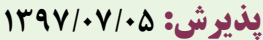

$$
\begin{aligned}
& \text { وازههاى كليدى } \\
& \text { يردازش حسى } \\
& \text { عصب روانشناختى } \\
& \text { آسيب بينايى }
\end{aligned}
$$

سالار فرامرزى، دانشيار تروه روانشناسى و

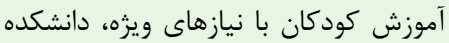
علوم تربيتى و وروانشناسى، دانشكاه اصفهان، اصفهان، ايران ايميل:: S.faramarzi@edu.ui.ac.ir

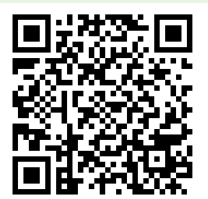

dol doi.org/10.30699/icss.21.3.52

مقرم)

افراد از خود و ديخران بسيار متفاوت خواهد بود. اين ادراك متفاوت ممكن است در افراد با آسيب بينايى، سبب بروز مشكلات عاطفى و اجتماعى گردد (ז). گَويا به نحو خاصى احساس مى كنيم كه از ميان همه طبقههاى آموزش ويزه، هيجكدام ناراحت كنندهتر از تعامل با افراد نابينا نيست. به نظر مىرسد آسيب بينايى نسبت به ساير ناتوانىها،
دانشآموزان با نيازهاى ويزه دانشآموزانى هستند كه براى دستيابى به بيشترين توان بالقوه خود به آموزش ويزه و خدمات وابسته نياز دارند. معمولاً اين افراد به يازده گروه تقسيم مىشوند. دانشآموزان با آسيب بينايى و نابينا يكى از اين كروهها هستند (l، ؟). نابينايى تأثيرات همه جانبهاى بر كاركردهاى فرد مى گذارد. بدون بينايى، ادراك و تفكر 
ادراك زمان، پِيشبينى آينده، بازسازى، زبان درونى و حل مسئله را

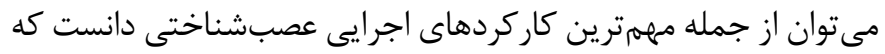
در زندكى و انجام تكاليف يادكيرى و كنشهاى هوشى به انسان كمك فئ

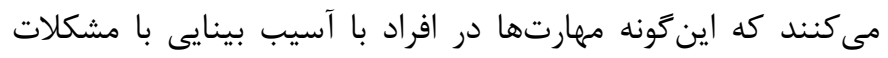
قابلتوجهى همراه مىباشد (ع) (1).

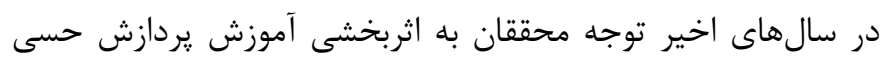

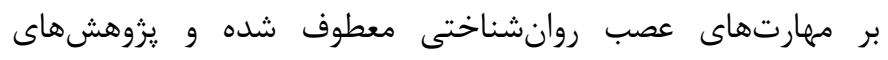
كستردهاى در اين زمينه انجام شده است. به عنوان مثال يافتههاى يزوهش Haegele و همكاران نشان داد كه خودكارآمدى، كاركردهاى

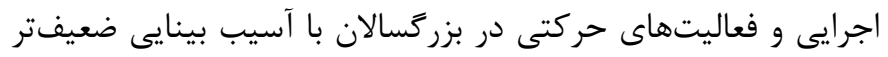
از بزرَسالان عادى است (IV). يافتههاى مطالعه Amira و Amira

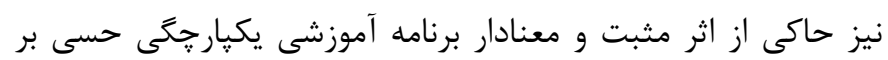

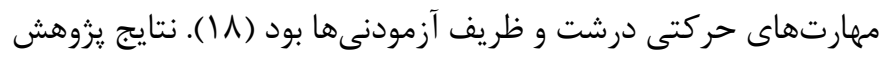
Iwanaga

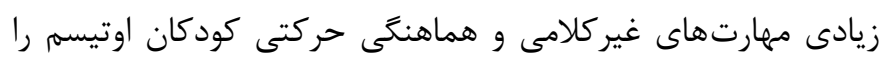
نسبت به گروه كنترل افزايش داده است (19). Devlin و همكاران

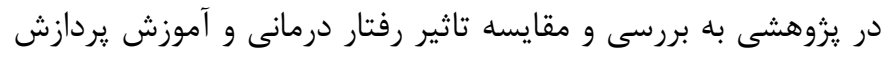
حسى به منظور كاهش رفتارهاى خودآسيبرسان يرداختند. يافتهها نشان داد كه هر دو روش موجب كاهش رفتارهاى خودآسيبرسان شد اهد ولى رفتاردرمانى در اين زمينه كاراتر بود (•(؟). ارجمندنيا و همكاران در يزوهشى به بررسى اثربخشى آموزش حركات ريتميك بر كاركردهاى

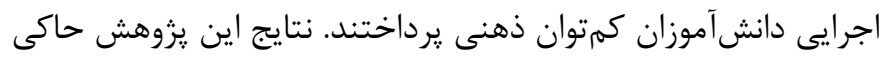

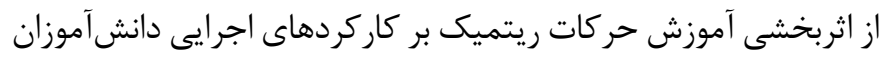

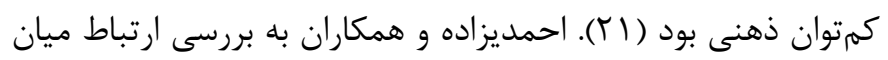
يردازش حسى و مهارتهاى حركتى در كودكان فلج مغزى يرداختند.

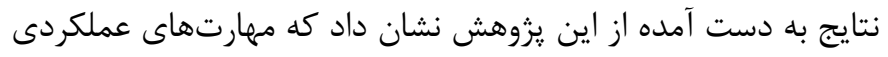
درشت و دستى در كودكان فلج مغزى با فاكتورهاى تونسيته و تحمل عضلانى يايين، ضعف ثبت حسى و بى تحركى ارتباط معنادار دارد (Tr). جمشيديان و همكاران به بررسى اثربخشى توانايىهاى يردازش إنى

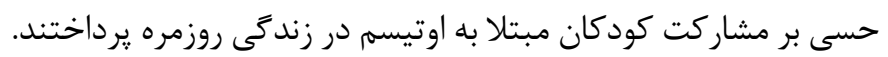

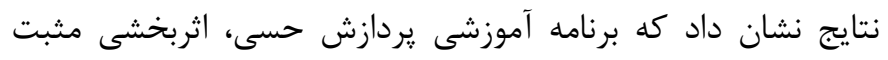

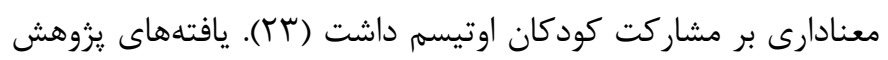

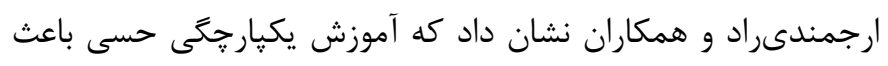

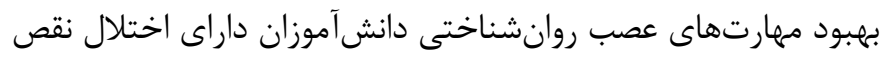

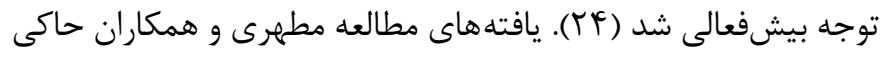
از آن بود كه يكيارجنى حسى بر نشانهاى بيش فعالى، نقص توجها

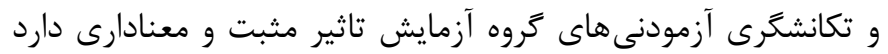

حركتهاى ناشيانهترى را به همراه دارند. علاوه بر اين، آسيب بينايى

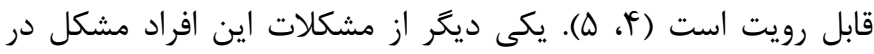
يردازش حسى است. يردازش حسى راهى است كه سيستم عصبى إنى إنى

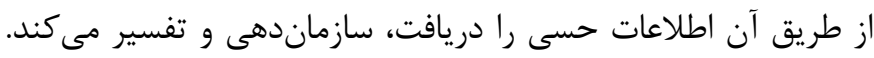

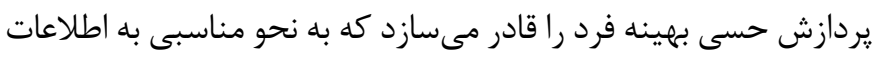

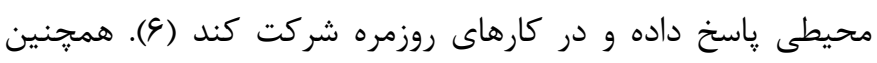

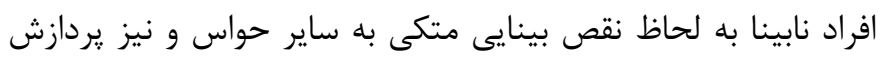

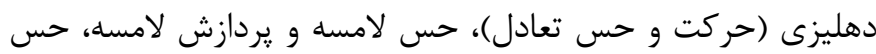

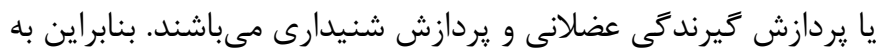
نظر مىرسد تحريكهاى حسى مناسب بتوانند به رشد و بهبود سيسته اعصاب مركزى و در نتيجه يادكيرى مهارتهاى حركتى و نوشتارى در

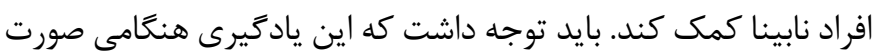

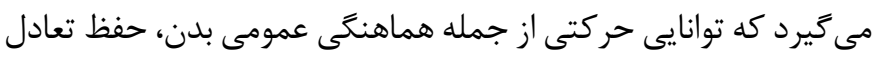

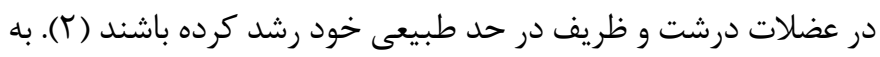

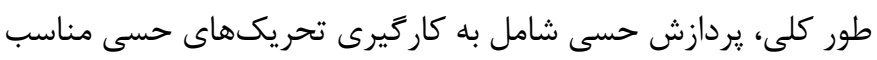

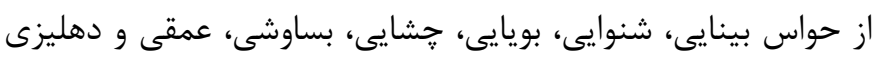

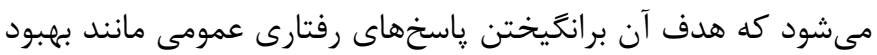
توجه يا برانگيختكى و ارتقاى عملكرد ادراكى، حركتى است (V).

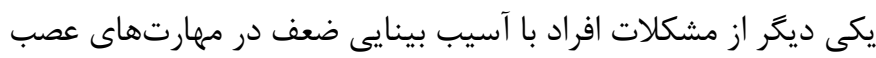
روانشناختى است. مهارتهاى عصب روانشناختى شامل مهارتهاى

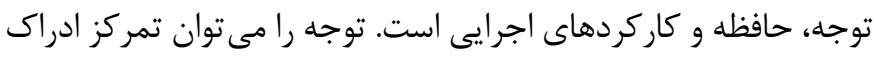
بر روى جنبه هاى خاصى از محرك يا محيط دانست كه موجب گسترش

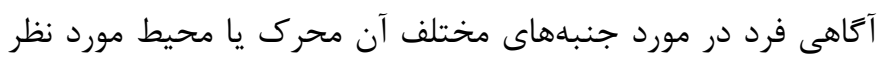

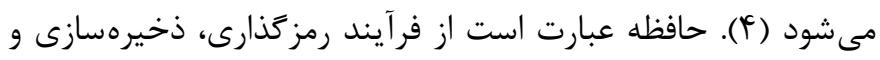

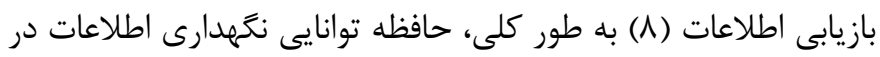

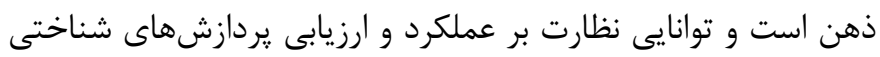

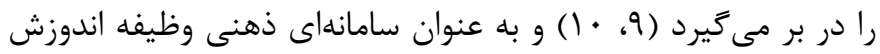

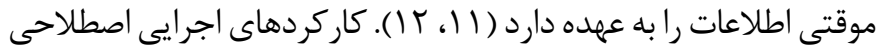
كلى است كه تمام فرايندهاى شناختى يِيجيده را كه در انجام تكاليف

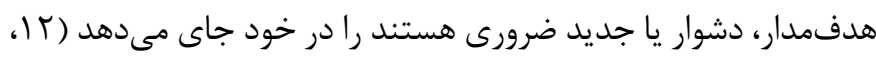

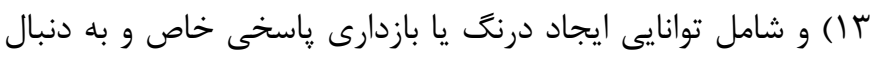

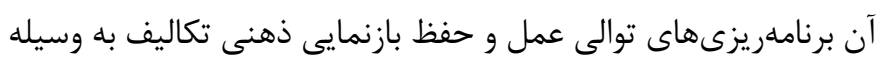

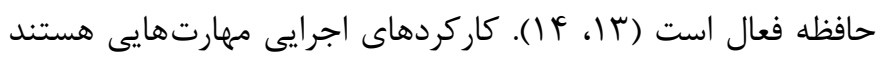

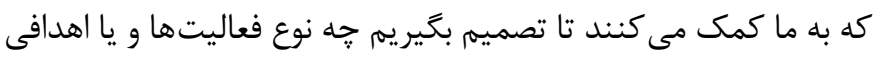
بايد مورد توجه قرار بخيرند، كدام يك انتخاب گردند و קحكونه رفتارها سازماندهى و برنامهريزى شوند (9). در واقع كاركردهايى همجون سازماندهى، تصميم گيرى، حافظه فعال، بازدارى حركتى، احساس و 
محاسبه شد. دليل استفاده از روش نمونه گيرى در دسترس، تعداد اندى

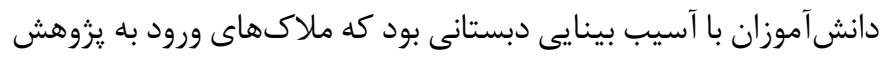

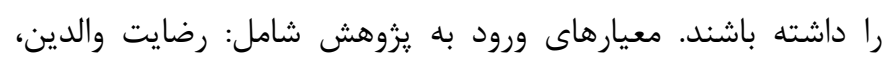

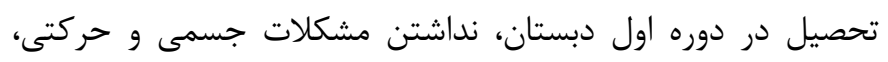

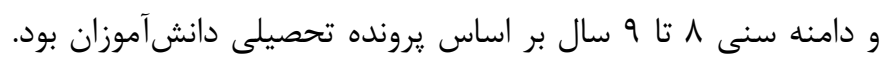

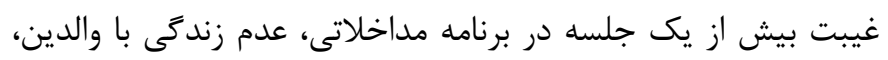

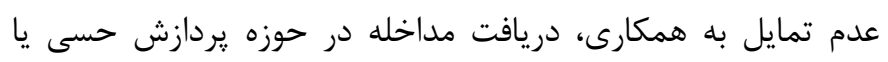

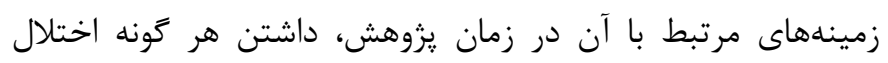

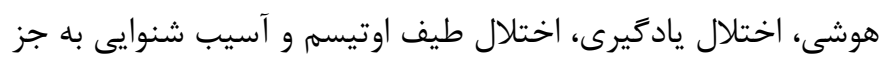

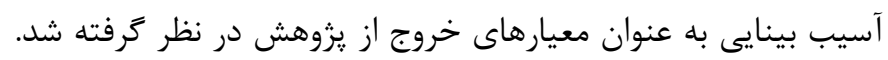
براى ارزيابى مهارتهاى عصب روانشناختى (توجه، حافظه، كاركرد

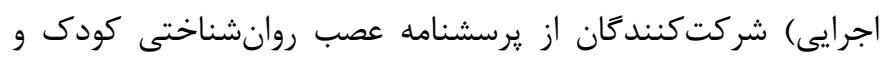
نوجوان Connors استفاده شد.

مقياس عصب روانشناختى كودى و نوجوان Connors:

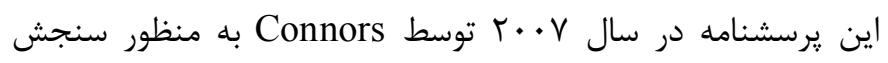

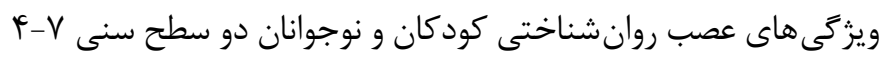

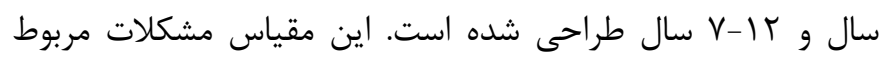
توجه، كاركردهاى اجرايى و حافظه را در جهار طيف ليكرتى (مشاهده

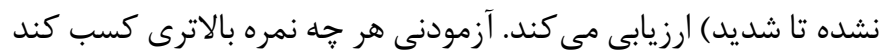

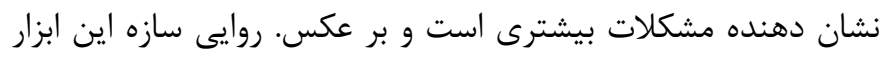

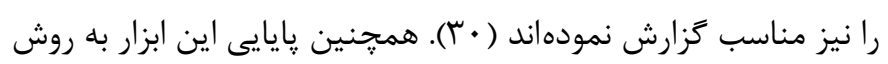

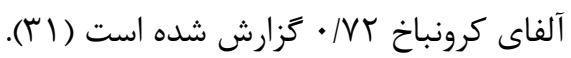

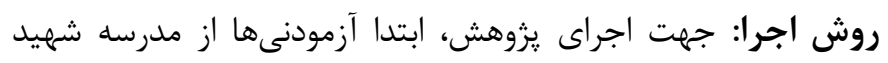

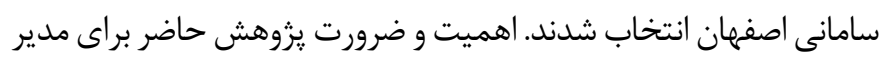

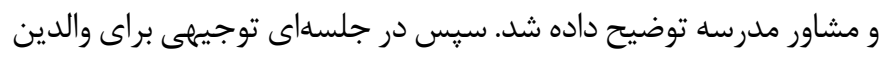
آزمودنىها، ضمن تشريح اهداف يزوهش از آنها خواسته شد تا رضايتنامه

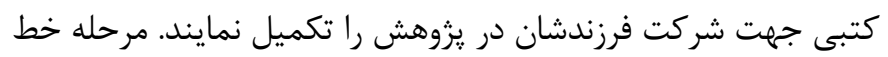

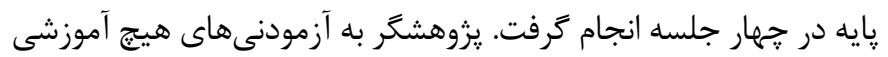

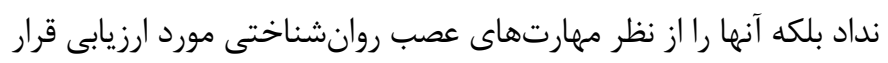

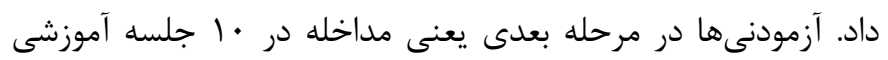

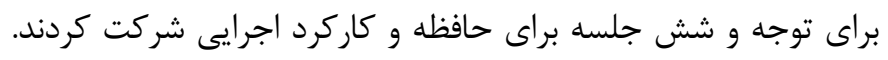

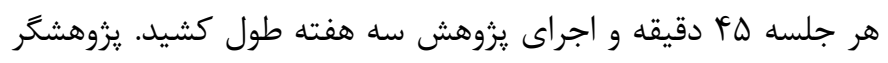

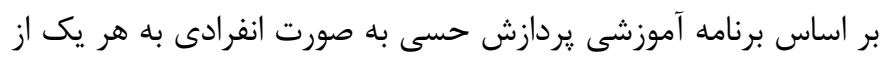

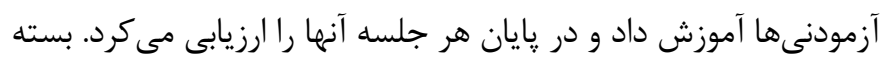

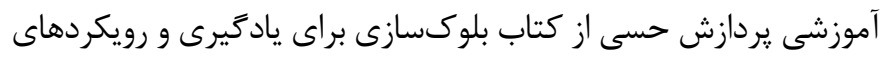

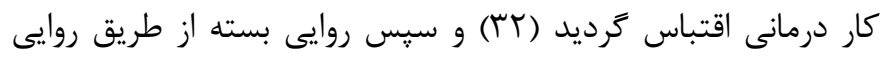

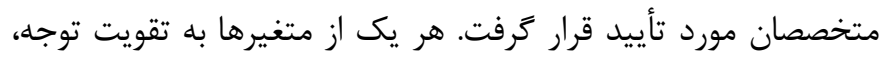

(TD). نجاتى در يزوهشى به مقايسه كاركردهاى اجرايى شناختى مغز

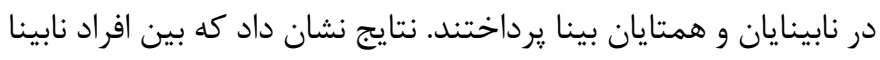

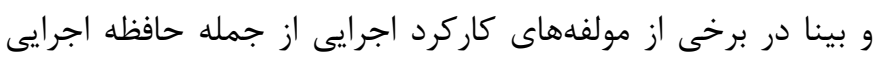

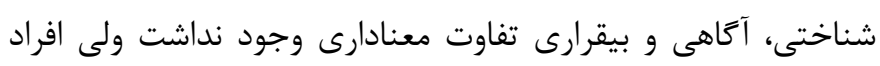

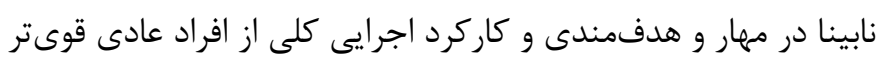

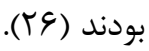

از آن جايى كه بردازش حسى از رويكردهاى مبتنى بر نظريه درمان

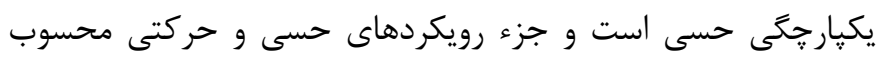

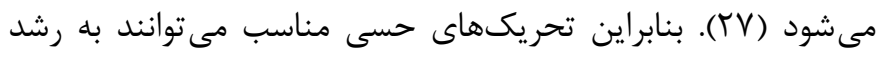

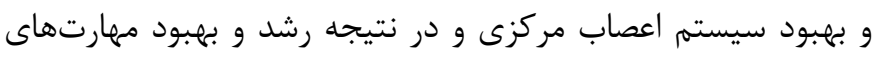

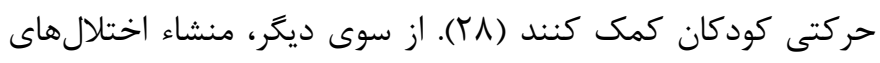

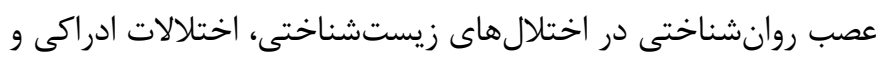

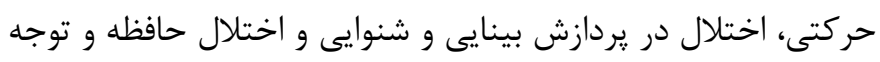

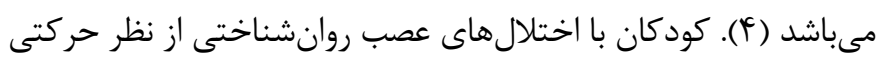

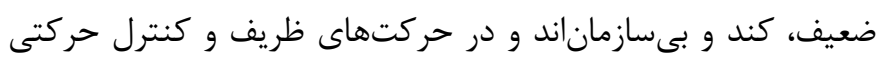

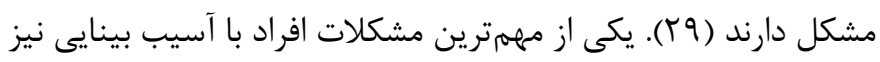

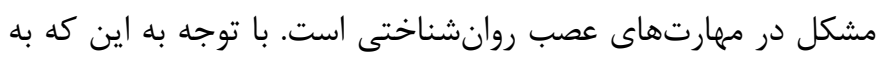

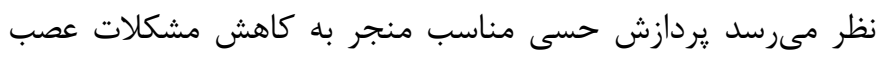

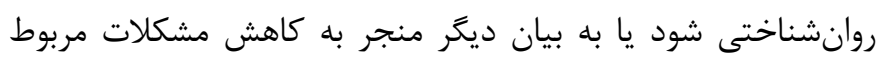

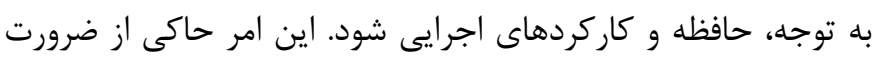

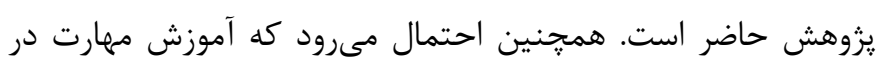

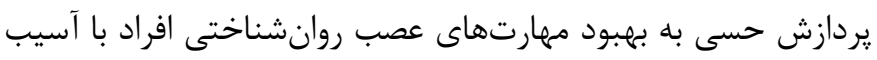

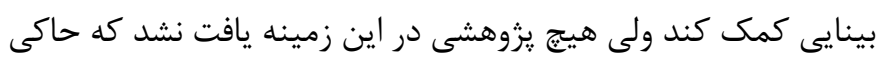

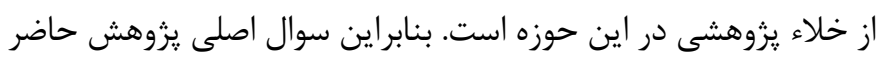

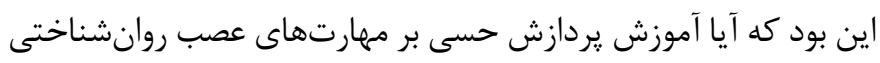

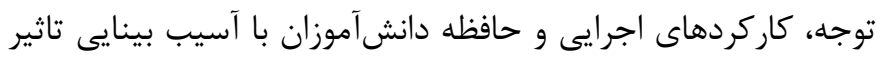
دارن؟

\section{روش كار}

يزوهش حاضر از نوع تك آزمودنى و با طرح خط پايه، مداخله و يِيكيرى

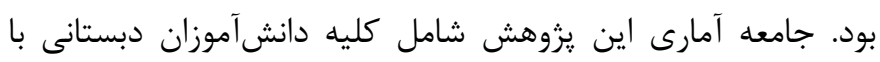

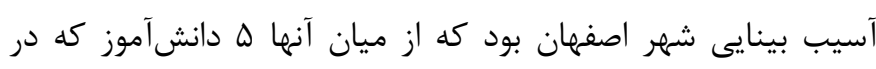
زمينه مهارتهاى عصب روانشناختى داراى مشكل بودند با استفاده

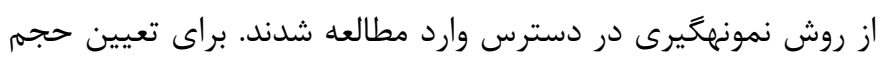

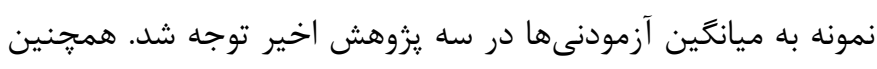

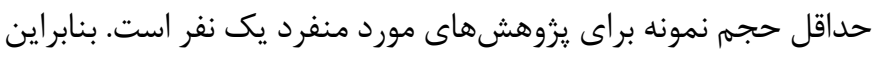

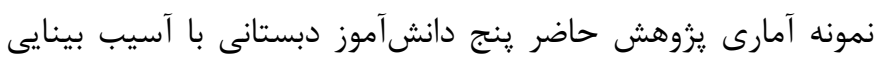


آزمودنى در سه موقعيت خط يايه، مداخله و پييخيرى به صورت جدول

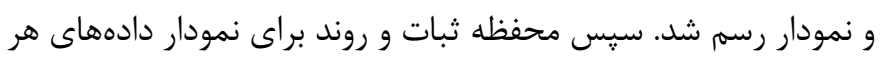

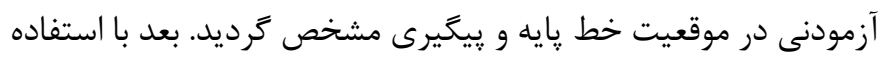

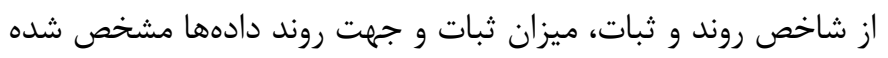
و در نهايت با استفاده از روش تحليل درون موقعيتى و بين موقعيتى به ديه

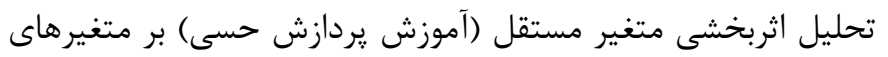

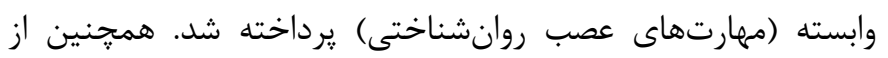

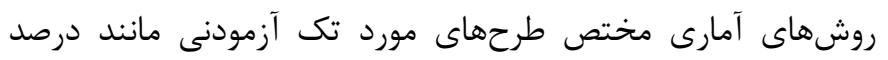

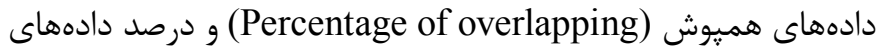
ناهميوش (Percentage of overlapping) استفاده شد.
كاركردهاى اجرايى و حافظه كمك مى كنند. به همين دليل تعداد جلسات

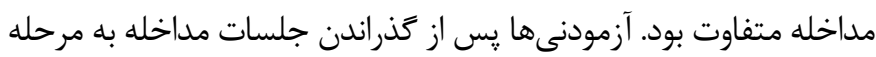

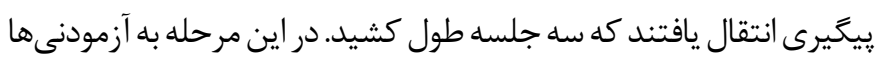

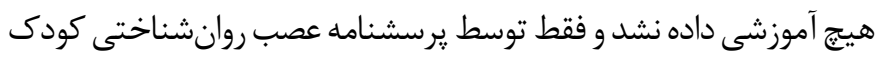

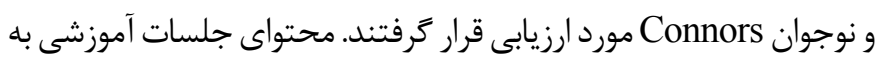
تفكيك جلسهها در جدول آ آمده است. دادههاى به دست آمده از اين سه موقعيت آزمون، يعنى خط خدائه

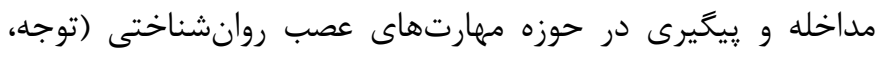

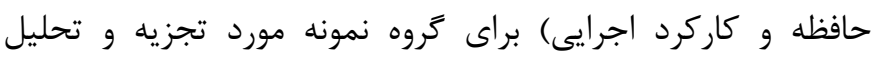

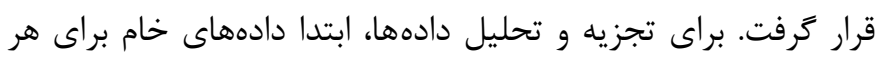

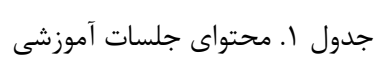

\section{محتوا}

جلسات

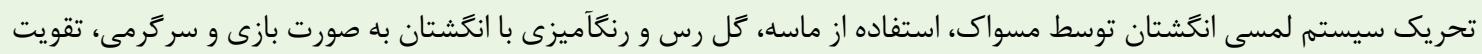

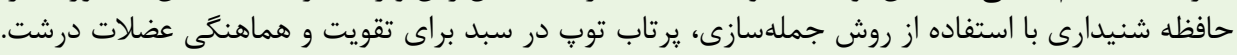

جلسه اول

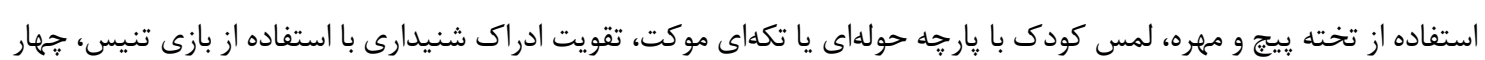

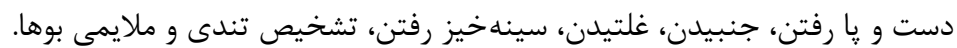

جلسه دوم

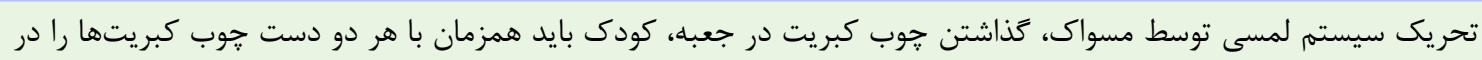

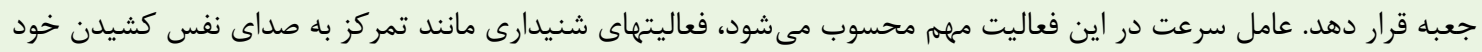

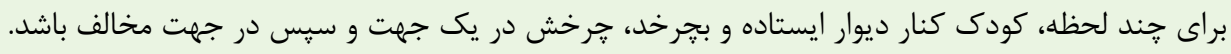

جلسه سوم

ييدا كردن تفاوتها و شباهتها در اشياء مثل حيوانات، تشخيص جهات صداها و توضيح راجع به آنها، استفاده از تخته يرش جهت تحريك سيستم وستيبولار.

جلسه جهارم

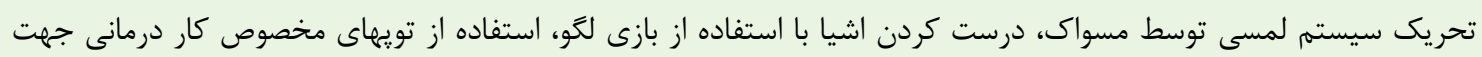

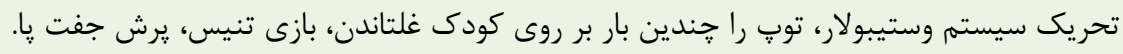

جلسه קنـمم

لمس كودى با يارجه حولهاى يا تكهاى موكت، تقويت حافظه شنيدارى با استفاده از روش جملهسازى، غلتاندن توٍ روى ديوار،

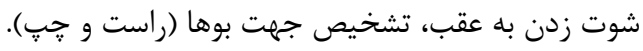

جلسه ششم

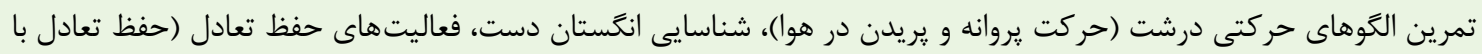

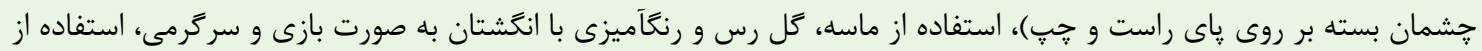

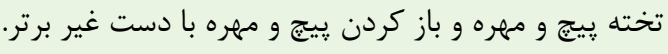

جلسه هفتم

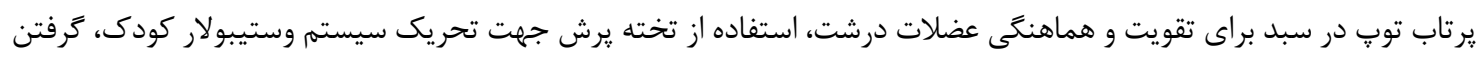

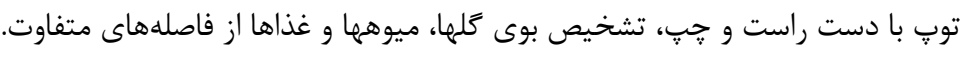

جلسه هشتم

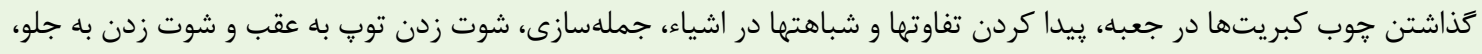

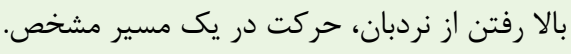
جلسه نهر

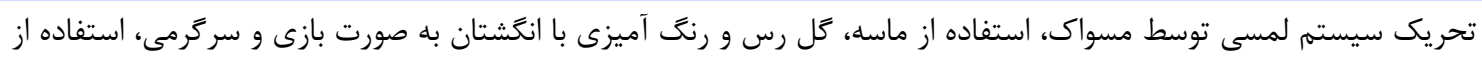

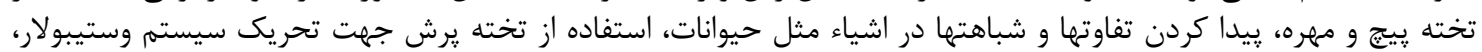

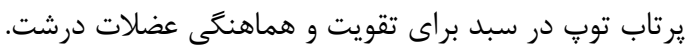




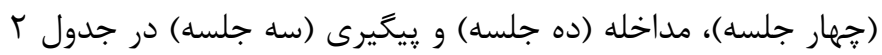

بافتهه ها در اين يزوهش ينج دانشآموز 1 تا 9 ساله با آسيب بينايى شركت نشان داده شده است. نتايج جدول r حاكى از آن است كه ميانكَين نمرات مشكلات مهارت

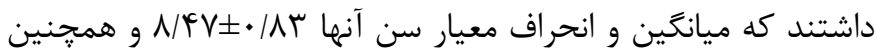
عصب روانشناختى توجه در جلسهها و موقعيتهاى مختلف تغيير يافته است. روند تغييرات در نمودار ا نشان داده شده است.

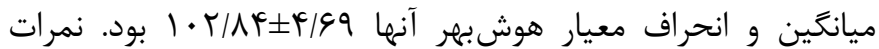
مهارت عصب روانشناختى توجه آزمودنىها در سه موقعيت خط پايه

جدول r. ميانَين نمرات مهارت عصب روانشناختى توجه آزمودنىها در سه موقعيت خط پايه، مداخله و بِيخيرى

\begin{tabular}{|c|c|c|c|c|c|c|c|c|c|c|c|c|c|c|c|c|c|c|}
\hline \multicolumn{3}{|c|}{ جلسات يِيخيرى } & \multicolumn{10}{|c|}{ جلسات مداخله } & \multicolumn{4}{|c|}{ جلسات خط يايه } & \multirow{2}{*}{$\begin{array}{l}\cdot \bar{g} \\
? \\
3\end{array}$} & \multirow{2}{*}{3} \\
\hline$r$ & $r$ & 1 & 1. & 9 & $\Lambda$ & $V$ & 9 & $\Delta$ & $p$ & $r$ & $r$ & 1 & $f$ & r & $r$ & 1 & & \\
\hline ז & rq/.. & $r \varepsilon / . r$ & $\{1 / 9 V$ & r & (I)/qV & $41 / 97$ & $\uparrow V / q$. & $\Delta \cdot / \Lambda \mathrm{V}$ & $\Delta T / A F$ & $\Delta 9 / V \Lambda$ & $\Delta \varepsilon / \Lambda)$ & GT/VD & GT/VQ & $\Delta 9 / v \wedge$ & $\Delta q / \vee \wedge$ & $\Delta 9 / v \wedge$ & 1 & \\
\hline FT/GD & Fr/GD & rN/GT & rN/GT & $r \cdot \mid \Delta \varphi$ & FT/GD & Fr/GD & $\forall \& 191$ & $\Delta \cdot / V I$ & $\Delta F / V F$ & GK/A. & $\Delta \Lambda / V V$ & $\Delta N / V V$ & $\Delta \Lambda / V V$ & GT/A. & $\Delta \Lambda / V V$ & $\Delta N / \Delta \Delta$ & $r$ & \\
\hline$r \Delta / r$. & $r \Delta / \tau$. & $r \Delta / r$. & $r N / \Delta \Delta$ & $\{1 / 91$ & FA/TG & $F \Delta / T^{\prime}$ & FNIGT & $01 / 9 V$ & $\Delta N / 9 \Lambda$ & $\Delta \Delta / \pi \mu$ & $G T / \cdot F$ & $\Delta N / 9 \Lambda$ & $\Delta N / 9 \Lambda$ & $\Delta N / 9 \Lambda$ & $G T / \cdot F$ & $\Delta N / 9 \Lambda$ & $r$ & g. \\
\hline ए१/१६ & ґ१/१४ & ५१/१९ & ५१/१९ & ५१/৭६ & FE/TK & $F F / r \mu$ & $F N / F q$ & $\Delta T / V G$ & $F N / F q$ & $F N / F q$ & DT/VG & $\Delta V / \cdot r$ & $\varphi \Delta / \Delta \varphi$ & $81 / 79$ & $\varphi \Delta / \Delta \varphi$ & $G \Delta / \Delta G$ & $f$ & \\
\hline 4.1 .9 & 4.1 .9 & rब/ & rब/IV & 4.1 .9 & 4.1 .9 & $\Delta / / A F$ & $\Delta I / A F$ & $\Delta Q / V \varphi$ & $\Delta \Delta / V \varphi$ & $\Delta 9 / 9 \wedge$ & $\Delta 9 / 9 \wedge$ & दर/द. & $\Delta 9 / 9 \wedge$ & $\Delta 9 / 9 \Lambda$ & $\Delta Q / 9 \wedge$ & $\Delta 9 / 9 \Lambda$ & $\Delta$ & \\
\hline
\end{tabular}

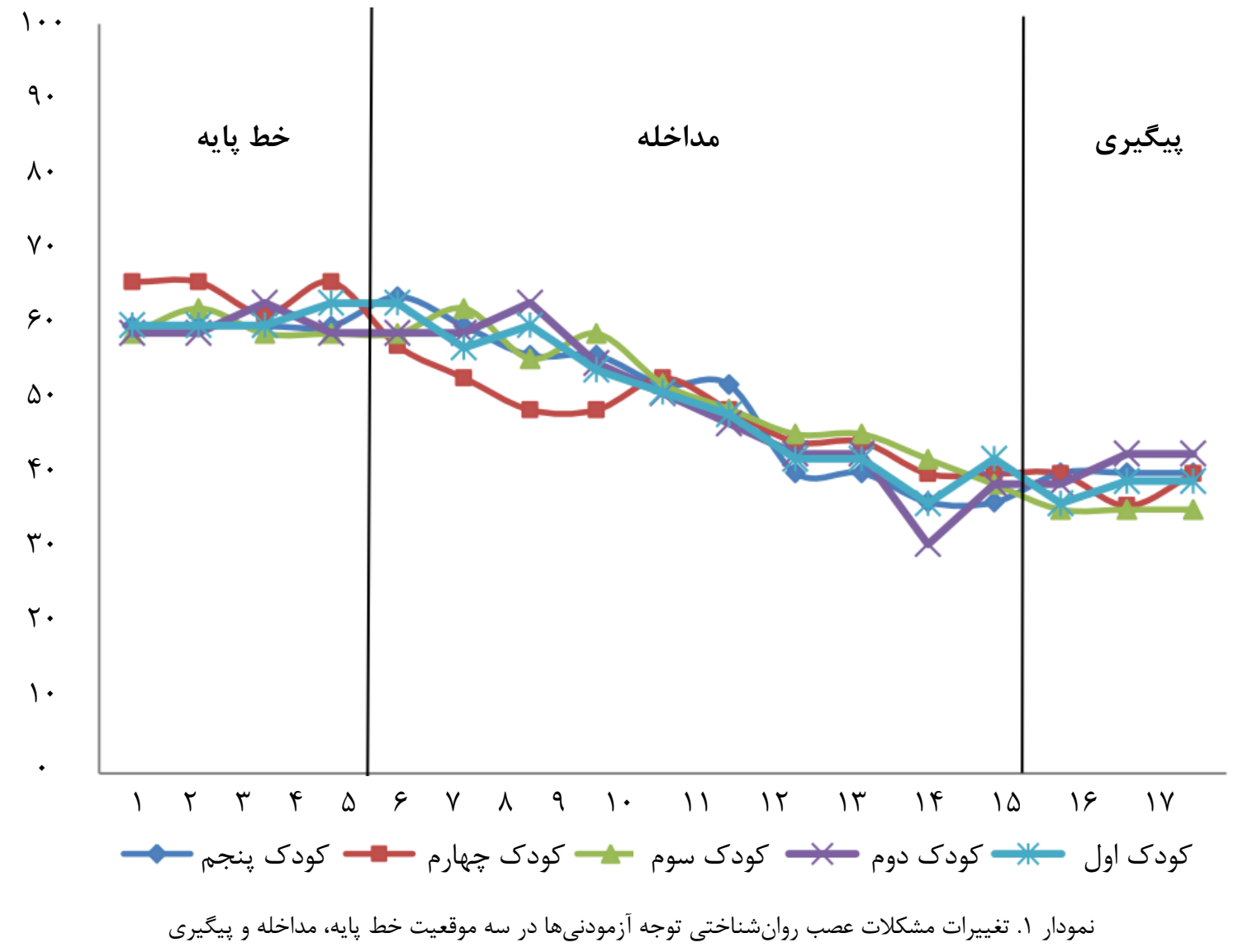


است. روند تغييرات در نمودار r به نمايش كذاشته شده است. بر اساس نمودار r، مشخص شد كه مشكلات حافظه در هر ينج شركت كننده با كذشت جلسههاى مداخله يردازش حسى كاهش يافته است. اين نمودار خط ميانه، خط روند و محفظه ثبات آزمودنىها را نشان مى هميوشى دادهها در آزمودنىها در جدول ه مشخص شده است. بر اين اساس نتايج جدول ه و با توجه به شاخص دادههاى ناهميوش،

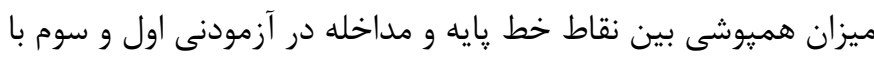
به درصد اطمينان و در ساير آزمودنىها با · ا درصد اطمينان مؤثر بوده است. نمرههاى متغير مهارت عصب روانشناختى كاركرد اجرايى آزمودنىها در سه موقعيت موقعيت خط پايه (سه جلسه)، مداخله (شش جلسه) و پيیگيرى (سه جلسه) در جدول 9 نشان داده شده است. نتايج جدول و حاكى از آن است كه نمرههاى مهارت عصب روانشناختى كاركرد اجرايى در جلسهها و موقعيتهاى مختلف تغيير يافته است.
بر اساس نمودار ا، مشخص شد كه مشكلات توجه در هر ينج شركت كننده با گذشت جلسههاى مداخله يردازش حسى كاهش يافته Stability) است. اين نمودار خط ميانه، خط روند و محفظه ثبات (Envelope در آزمودنى ها در جدول r مشخص شده است. بر اين اساس نتايج جدول r و با توجه به شاخص دادههاى ناهميوش،

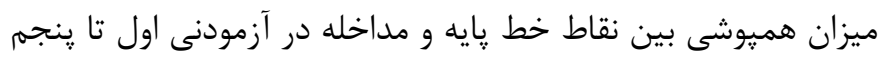

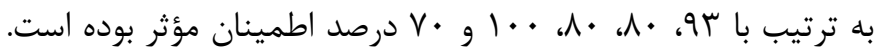
نمرههاى متغير مهارت عصب روانشناختى حافظه آزمودنىها در سه موقعيت خط يايه (سه جلسه)، مداخله (شش جلسه) و رييخيرى (سه جلسه) در جدول fا نشان داده شده است.

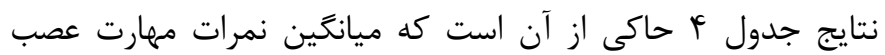
روانشناختى حافظه در جلسهها و موقعيتهاى مختلف تغيير يافته

جدول r. ميانگَين و هميوشى نمرههاى توجه در آزمودنىها

\begin{tabular}{|c|c|c|c|c|}
\hline دادههاى هميوش (درصد) & دادههاى ناهميوش (درصد) & مداخله & خط پايه & آمودنى \\
\hline 1. & 9. & $r q / r \Lambda$ & $G \cdot \mid \Delta T$ & 1 \\
\hline$r$. & $\wedge$. & $\forall N / \Delta q$ & $\Delta q / \vee \wedge$ & $r$ \\
\hline$r \cdot$ & $\wedge$. & $\Delta \cdot 194$ & $\Delta 9 / \Delta r$ & $r$ \\
\hline$\cdot$ & $1 \ldots$ & $F V / G F$ & $q 4 / 4 q$ & F \\
\hline$r$. & v. & $<q / 1$. & $\Delta Q / 9 V$ & $\Delta$ \\
\hline
\end{tabular}

جدول fا. ميانَين نمرات مهارتهاى عصب روانشناختى حافظه آزمودنىها در سه موقعيت خط پايه، مداخله و پِيگيرى

\begin{tabular}{|c|c|c|c|c|c|c|c|c|c|c|c|c|c|}
\hline \multicolumn{3}{|c|}{ جلسات ييگيرى } & \multicolumn{6}{|c|}{ جلسات مداخله } & \multicolumn{3}{|c|}{ جلسات خط يايه } & \multirow{2}{*}{$\begin{array}{l}\bar{r} \\
\hat{g} \\
\cdot \mathfrak{y}\end{array}$} & \multirow{2}{*}{$: 3$} \\
\hline$r$ & $r$ & 1 & 9 & $\Delta$ & $p$ & $r$ & $r$ & 1 & $r$ & $r$ & 1 & & \\
\hline . & rr/G. & $r V / \Lambda \Lambda$ & F्वाT & $\mathrm{Fq} / \mathrm{V}$. & $\Delta r / T \Lambda$ & $\Delta \Delta / \cdot V$ & $\Delta G / \Lambda G$ & $\Delta \Lambda / \varphi \Delta$ & $\Delta \Lambda / \varnothing \Delta$ & $\Delta N / 9 \Delta$ & $\Delta \Lambda / \varphi \Delta$ & 1 & \\
\hline$r .1 .4$ & 4.1 .9 & $r F / A \Lambda$ & 4.1 .4 & $\Delta \cdot / \& r$ & $F \Delta / T \Delta$ & $\Delta \cdot / / F r$ & $\Delta \Delta / G Y$ & $\Delta \Delta / \varepsilon T$ & $90 / 99$ & $9 \cdot 11$. & $4 \cdot 11$. & $r$ & \\
\hline$r \cdot / \kappa \Delta$ & $r F / g q$ & $F r / \cdot r$ & $\{V / T)$ & $\mid F / T I$ & $\Delta 1 / f$. & $\Delta 1 / \kappa$. & $\Delta \Delta / \Delta q$ & $\Delta ৭ / \vee \wedge$ & $\Delta ৭ / \vee \wedge$ & $\Delta q / \vee \wedge$ & $\Delta ৭ / \vee \wedge$ & $r$ & $\bar{\Lambda}$. \\
\hline rr/G9 & TN/TT & FT/VA & FT/VA & FT/VA & FV/TF & $\Delta 1 / 9$. & $\Delta G / \varphi G$ & $91 / . r$ & $91 / \cdot r$ & $41 / . r$ & $91 / . T$ & $p$ & 3 \\
\hline$r V / r$. & re/A. & $F r / l F$ & $F q / F V$ & $F q / f V$ & $F q / f V$ & $\Delta r / G Y$ & $\Delta \Delta / \Lambda)$ & $\Delta \Lambda / 9 V$ & $\Delta \Lambda / q V$ & $\Delta N / 9 \vee$ & $\Delta \Lambda / q V$ & $\Delta$ & \\
\hline
\end{tabular}




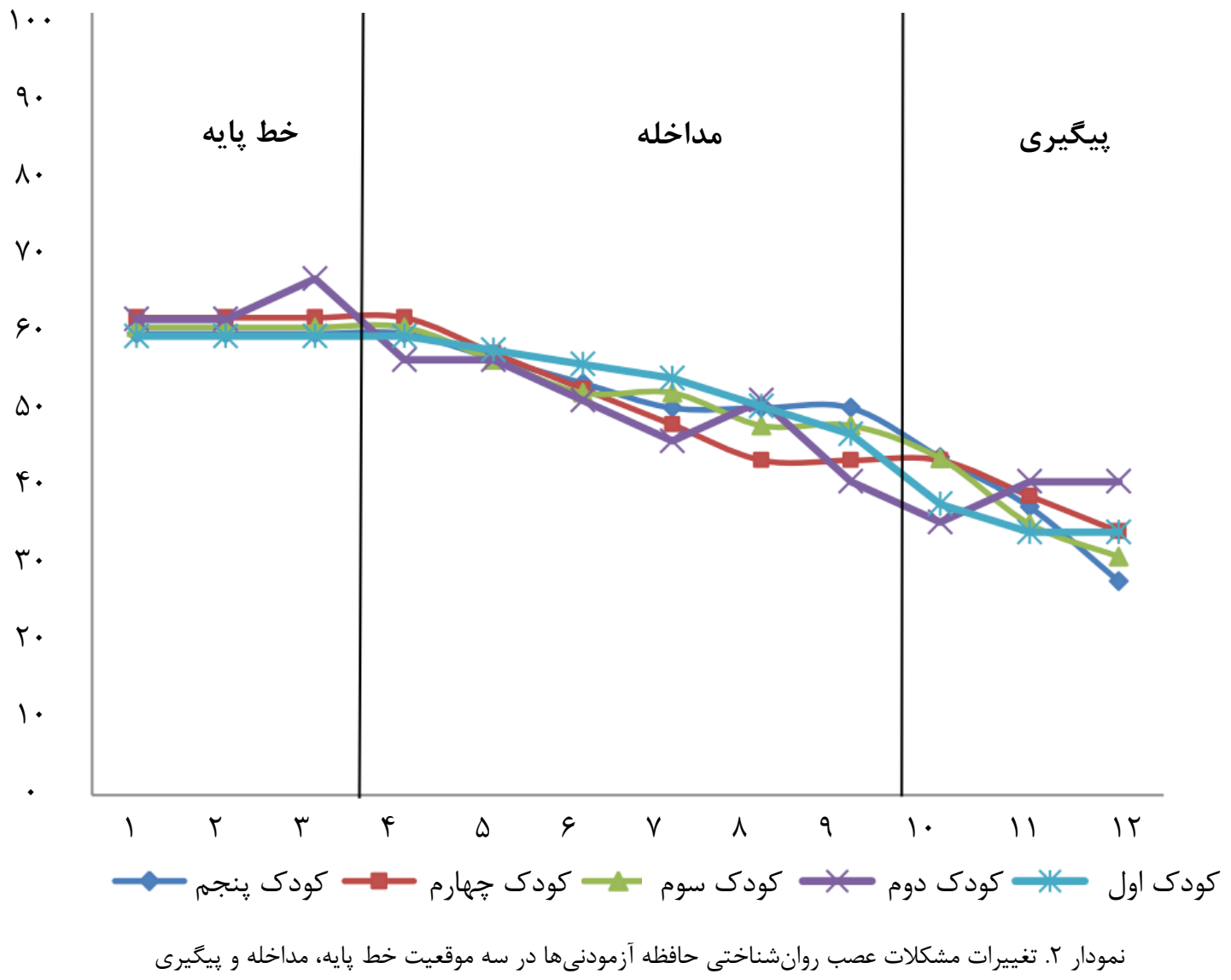

مشخص شده است. روند تغييرات در نمودار ب به نشان داده شده است. بر اساس نمودار س، مشخص شد كه مشكلات كاركرد اجرايى در هر بر اين اساس نتايج جدول V و با توجه به شاخص دادههاى ناهميوش، ينج شركت كننده با كذشت جلسهاى مداخله يردازش حسى كاهش ميزان هميوشى بين نقاط خط يايه و مداخله در آزمودنى اول تا

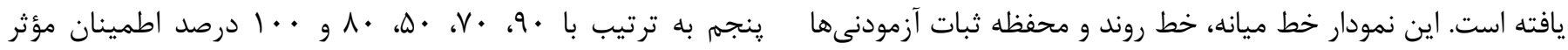
را نشان مى دهد. ميانگين و هميوشى دادها در آزمودنىها در جدول V V ل بوده است.

جدول ه. ميانخين و هميوشى نمرههاى حافظه در آزمودنىها

\begin{tabular}{|c|c|c|c|c|}
\hline دادههاى هميوش (درصد) & دادههاى ناهميوش (درصد) & مداخله & خط يايه & آزمودنى \\
\hline $19 / 9 V$ & זس/א1 & $\Delta \Pi / K \Lambda$ & $\Delta \Lambda / G Y$ & 1 \\
\hline . & $1 \ldots$ & $\uparrow q / \Delta q$ & GY/QT & $r$ \\
\hline $1919 \mathrm{~V}$ & سז/או & $\Delta r / \cdot q$ & $\Delta q / V \nabla$ & $r$ \\
\hline - & $1 \ldots$ & $\Delta \cdot / r V$ & $91 / \cdot 1$ & f \\
\hline . & $1 \ldots$ & $\Delta r / G r$ & $\Delta \Lambda / 9 \vee$ & $\Delta$ \\
\hline
\end{tabular}


جدول 9. ميانگَين نمرات مهارتهاى عصب روانشناختى كاركرد اجرايى آزمودنىها در سه موقعيت خط پايه، مداخله و پيخيرى

\begin{tabular}{|c|c|c|c|c|c|c|c|c|c|c|c|c|c|}
\hline \multicolumn{3}{|c|}{ جلسات ييگيرى } & \multicolumn{6}{|c|}{ جلسات مداخله } & \multicolumn{3}{|c|}{ جلسات خط هايه } & \multirow{2}{*}{$\begin{array}{l}\overline{1} \\
\bar{g} \\
\cdot\end{array}$} & \multirow{2}{*}{ :3 } \\
\hline r & $r$ & 1 & 9 & $\Delta$ & $f$ & r & $r$ & 1 & r & $r$ & 1 & & \\
\hline$|\xi| .$. & ५ /.. . & r & \&V/q. & $\Delta \cdot / \Lambda V$ & $\Delta r / \Lambda F$ & $\Delta ৭ / \vee \wedge$ & $\Delta \varepsilon|\Lambda|$ & GT/VQ & $\Delta 9 / v \Lambda$ & $\Delta 9 / v \wedge$ & $\Delta 9 / v \wedge$ & 1 & \\
\hline$F T / G D$ & $F Y / \& D$ & TN/GT & 49191 & $\Delta \cdot / N \mid$ & $\Delta F / V F$ & gr/A. & $\Delta N / V V$ & $\Delta \Lambda / V V$ & GK/A. & $\Delta N / V V$ & $\Delta N / \Delta \Delta$ & $r$ & b \\
\hline$r \Delta / r$. & $r \Delta / r$. & $r \Delta / r$. & FNIGT & $\Delta 1 / 9 V$ & $\Delta \Lambda / \varepsilon \Lambda$ & $\Delta \Delta / r \mu$ & $G T / \cdot F$ & $\Delta N / 9 \Lambda$ & $\Delta N / 9 \Lambda$ & $G T / \cdot F$ & $\Delta N / 9 \Lambda$ & r & $\bar{\Lambda}$. \\
\hline ५ १/१९ & एव/१९ & ५१/१९ & $F N / F q$ & $\Delta T / V G$ & $F N / F q$ & $F / / 4 q$ & $\Delta T / V G$ & $\Delta V / \cdot r$ & $91 / 49$ & $Q \Delta / \Delta A$ & $Q \Delta / \Delta G$ & $p$ & $\dot{j}$ \\
\hline 4.1 .9 & 4.1 .9 & rq/।V & $\Delta I / A F$ & $\Delta \Delta / V G$ & $\Delta \Delta / V \varphi$ & $\Delta 9 / 9 \wedge$ & $\Delta 9 / 9 \wedge$ & GK/G. & $\Delta 9 / 9 \Lambda$ & $\Delta 9 / 9 \Lambda$ & $\Delta 9 / 9 \Lambda$ & $\Delta$ & \\
\hline
\end{tabular}

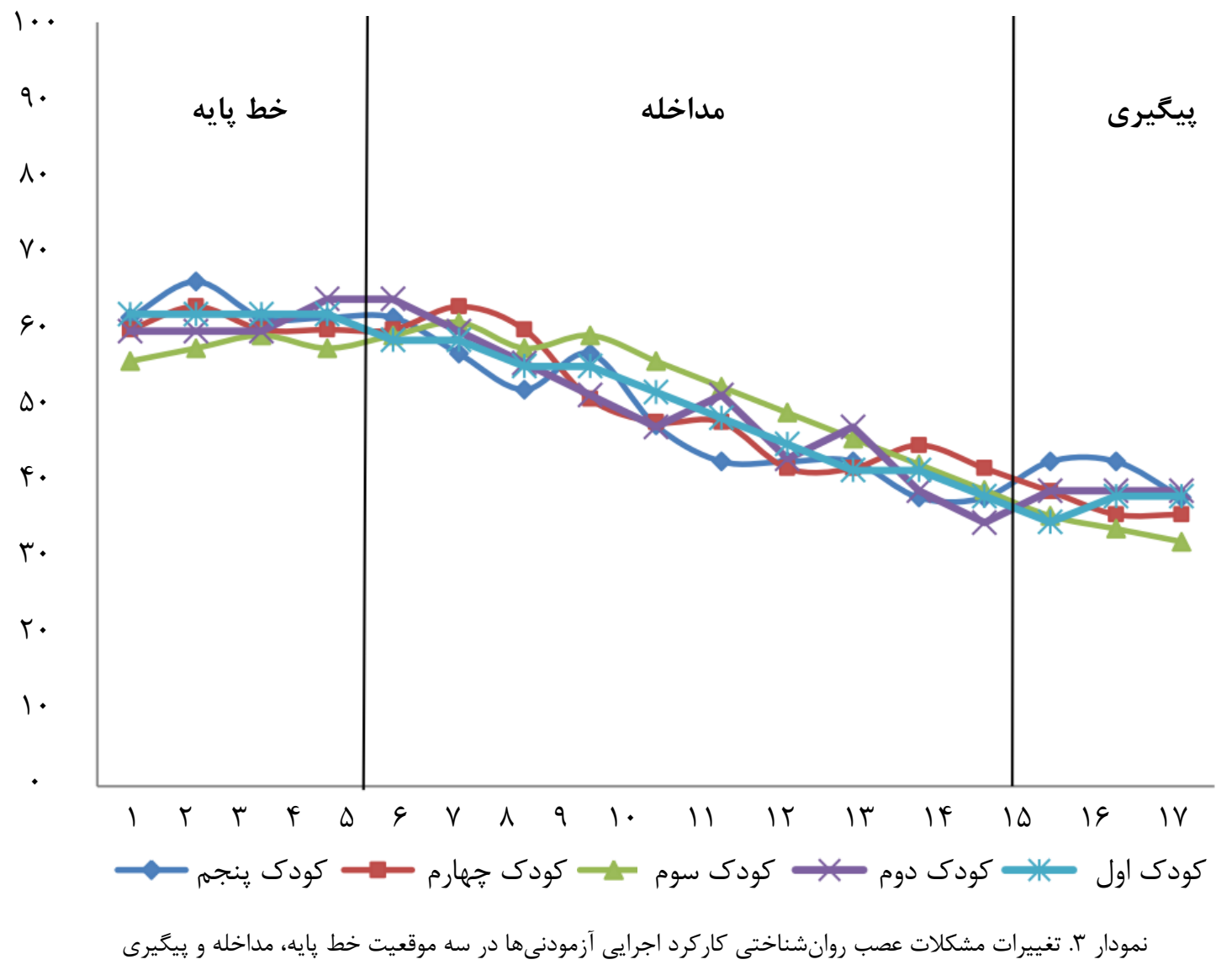

كاركردهاى اجرايى آزمودنىها را بهبود بخشيده است. به طور كلى، يافتههاى يزوهش حاضر با نتايج يزوهش Haegele و همكاران (IV)

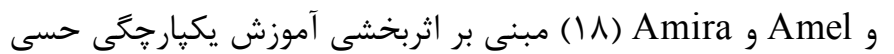
بر مهارتهاى حركتى كودكان با اختلال طيف اتيسم همسو بود. با يافتههاى مطالعه Devlin و همكاران نيز به خاطر تاثير قابل توجه
يزوهش حاضر با هدف بررسى تأثير آموزش يردازش حسى بر مهارتهاى عصب روانشناختى توجه، حافظه و كاركردهاى اجرايى دانشآموزان با آسيب بينايى در شهر اصفهان انجام شد. نتايج حاصل از تحليل ديدارى نمودار دادهها حاكى از آن بود كه آموزش يردازش حسى به مقدار قابل توجهى مهارتهاى عصب روانشناختى توجه، حافظه و 
مهارتهاى عصب روانشناختى كودكان كمك خواهد شد. مجموعهاى

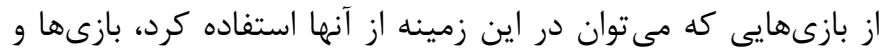
فعاليتهاى مبتنى بر آموزش يردازش حسى هستند (ها). در تبيين

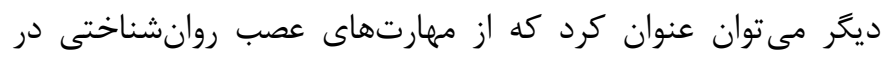

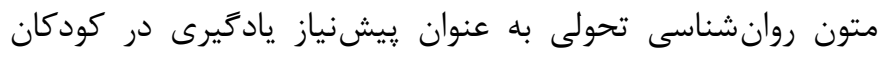

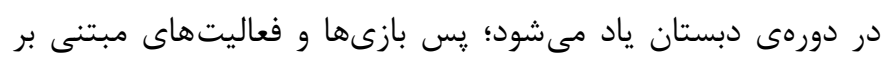

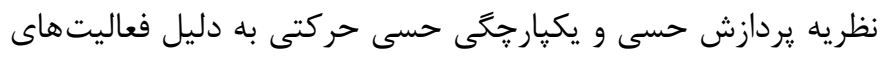
شناختى و رشدى مناسب آن كه همرا با شادى و به صورت جذاب جلى بهاب اجرا مىشود عليرغم اثرات آن بر سلامت جسمانى و شادى كودكان باعث رشد مهارتهايى عصب روانشناختى توجه، حافظه و كاركردهاى

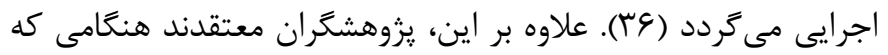

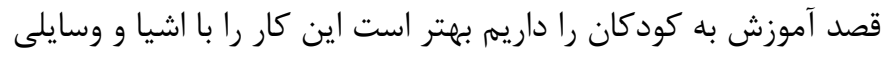

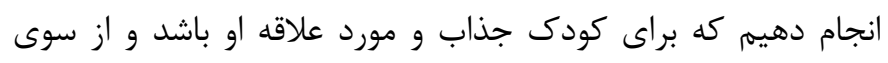

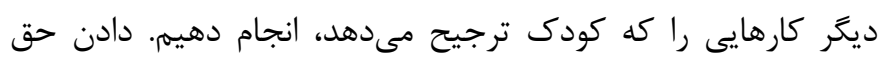

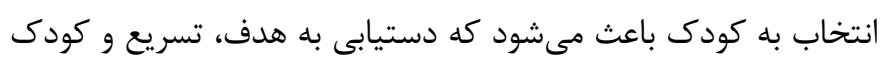

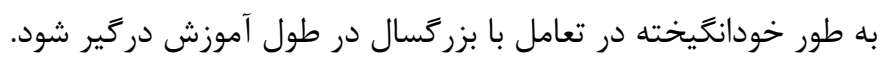
بازىها و فعاليتهاى مبتنى بر آموزش يردازش حسى با كاربرد اين

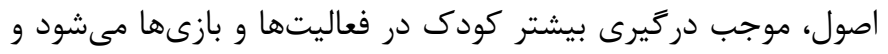
مىتواند به شكل قابل توجهى باعث بهبود مهارتهايى عصبى رشدى

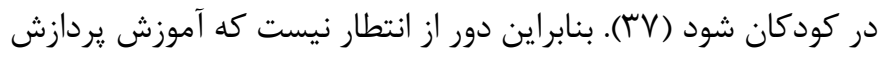
حسى منجر به بهبود مهارتهاى عصب روانشناختى توجه، حافظه

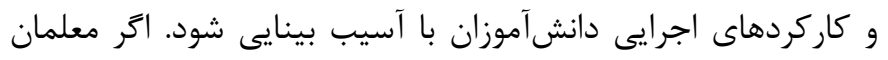

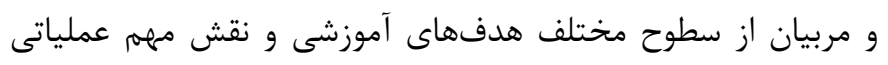

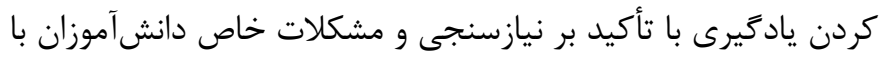

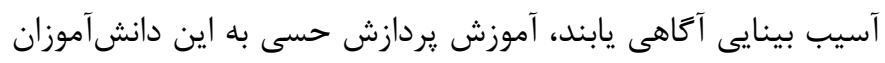

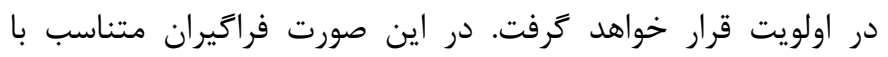

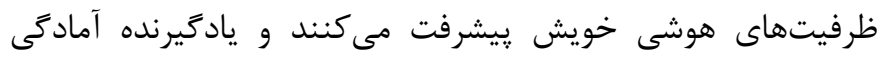
مقابله با جالشهاى زندگى روزمره خود را كه در ارتباط با توجه و حافظه و كاركردهاى اجرايى است را در خود احساس خواهد كرد. در

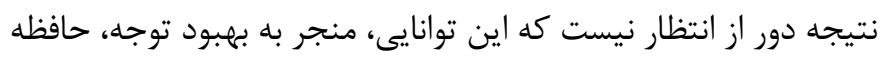

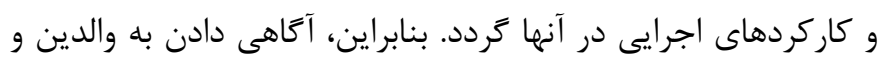

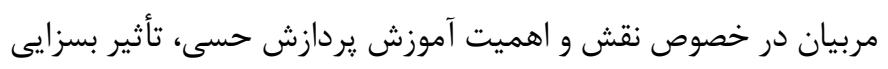

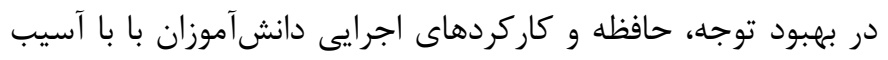
بينايى خواهد داشت.

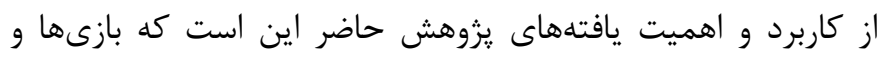

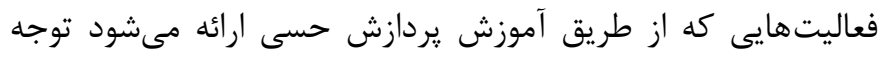

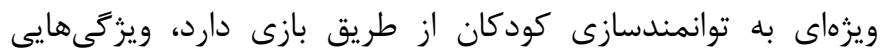

آموزش يردازش حسى بر كاهش رفتارهاى خودآسيبرسانى همخوانى

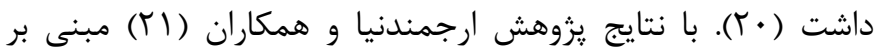
اثربخشى آموزش حركات ريتميك بر كاركردهاى اجرايى دانشآمآموزان

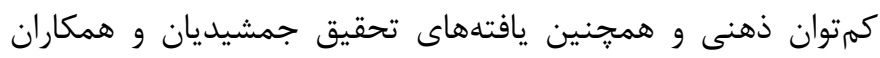
(r) مبنى بر اثربخشى توانايىهاى يردازش حسى بر مشاركت كودكان

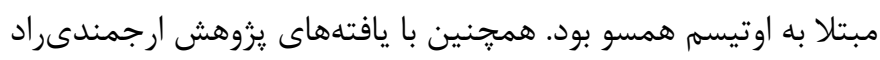

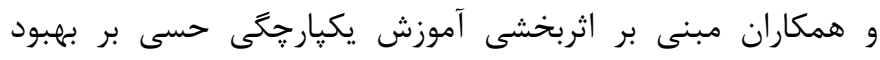
مهارتهاى عصبروانشناختى دانشآموزان داراى اختلال نقص توجه

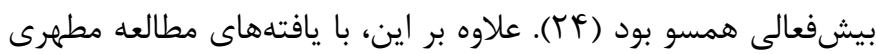

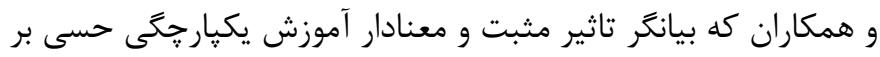
كاهش نشانهاى بيش فعالى، نقص توجه و تكانشكرى آزمودنى ها بود

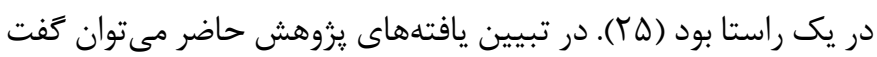

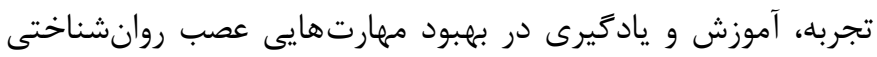

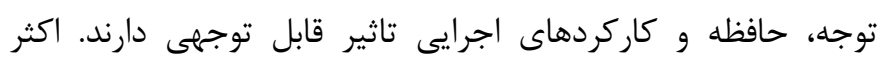

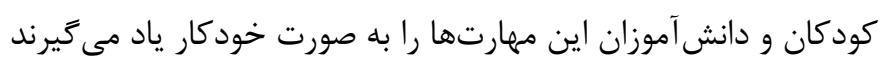

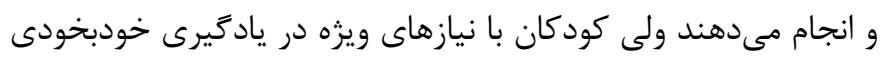

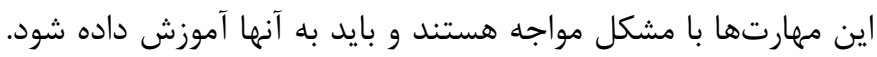

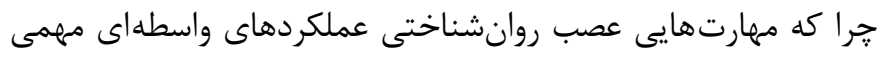
هستند و نظامهاى ييجيده و هدفمندى را به وجود مى آورند كه بايه شناخت را تشكيل مىدهند. رشد اين مهارتها در رشد همه جانبه

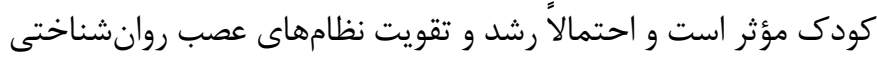

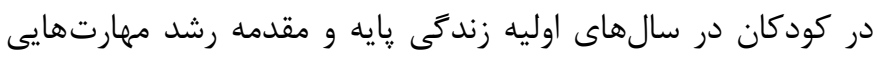

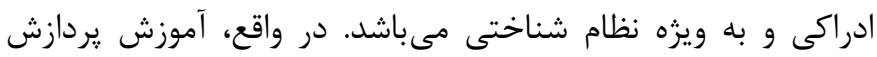

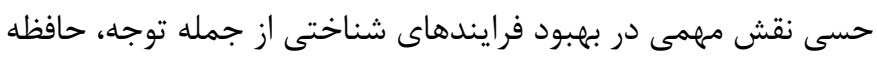

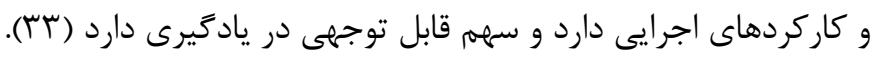

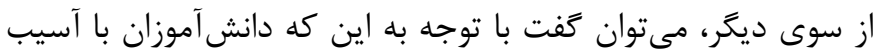
بينايى اغلب در رويارويى با مسائل و رسيدن به اهداف با شكست مواجه مىشوند، در مقابل شكست تسليم مى

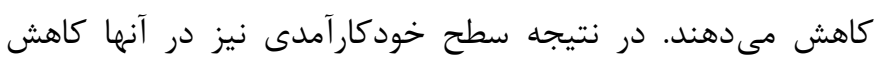

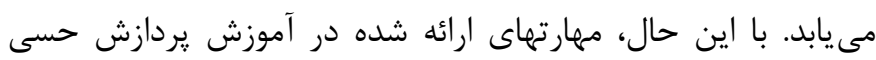

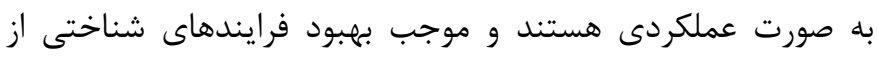

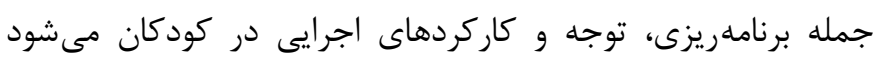

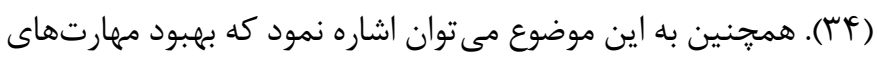
عصب روانشناختى تا حدود زيادى به تجارب دانشآموز ارتباط دارد.

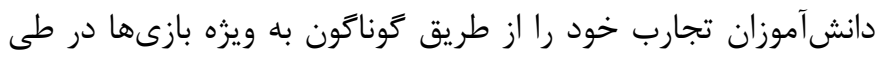
دوران رشد به دست مى آورند. بنابراين، اكر بتوان به غنى سازى محيط

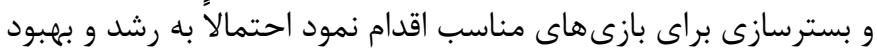


نيز به كار برده شود؛ با توجه به نتايج اين يزوهش، يكيج آموزشى و

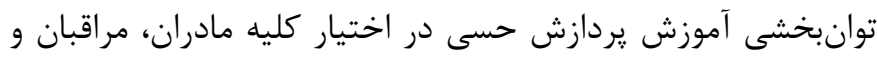

$$
\text { مربيان كودكان با آسيب بينايى قرار كيرد. }
$$

\section{نتيجه كَيرى}

بنابراين مى توان نتيجه كرفت كه آموزش يردازش حسى بر مهارتهاى

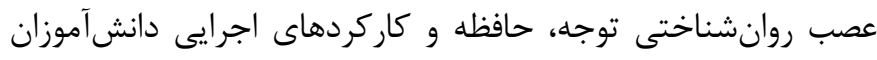

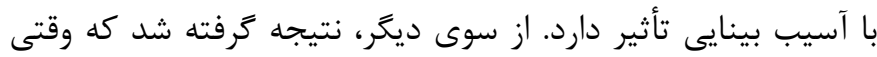
مراحل و مؤلفههاى مهارتهاى عصب روانشناختى در بستر فعاليتها و بازىهاى مبتنى بر آموزش يردازش حسى آموخته شود، اين امر

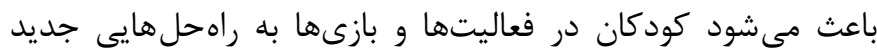
و مفيد دست يابند، ايدههاى مختلف و افزايش انخيزش در آنها ايجاد

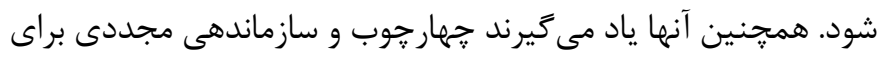

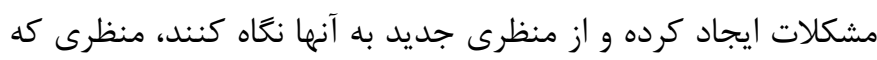

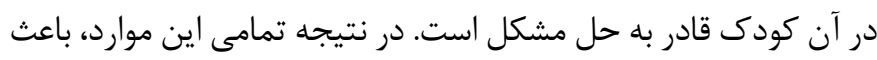

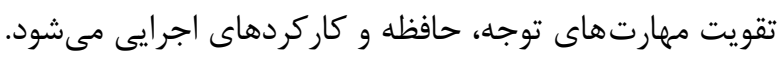

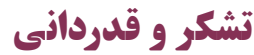

در اين يزوهش كودكان با آسيبهاى بينايى و نيز خانوادههاى ايشان و و ودمان

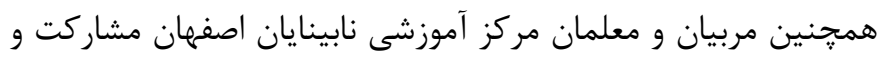

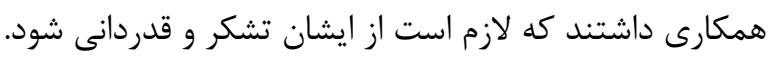

\section{References}

1. Kirk S, Gallagher G, Coleman MR. Educating exceptional children. 14th ed. Massachusetts:Wadsworth Publishing;2015. 2. Ashori M, Jalil-Abkenr SS. Students with special needs and inclusive education. 1st ed. Tehran:Roshd-e Farhang;2016. (Persian)

3. Brinol P, Petty RE, Rucker DD. The role of meta-cognitive processes in emotional intelligence. Psicothema. 2006;18(Supl):26-33.

4. Hallahan DP, Kauffman JM, Pullen PC. Exceptional learners: An introduction to special education. 13th ed. New Jersey:Pearson Education;2015.

5. Ashori M, Ghaforian M, Jalil-Abkenr SS. Students with vi-
همجون باور داشتن خود، تلاشگر بودن و تسليم نشدن را در كودى تقويت مىكند و زمينه را براى بهبود توجه، حافظه و كاركردهاى اجرايى فراهم مىنمايد. از طرفى يزوهش با محدوديتهايى مواجه بود كه مىتوان به جند مورد مهلم اشاره كرد: با توجه به اين كه محدوده سنى اين كودكان در سطح دبستان بود، لذا در تعميم نتايج بدست آمده به سايركروههاى سنى بايد جانب احتياط را رعايت نمود؛ آرَجه روش هاى تحقيق تك آزمودنى بهترين روشى است كه مىتوان در حوزه كودكان با نيازهاى ويزه مورد استفاده قرار داد ولى استفاده از تعداد كم نمونها مى تواند يك محدوديت باشد؛ اثربخشى آموزش يردازش بر مهارتهاى عصب روانشناختى توجه، حافظه و كاركردهاى اجرايى دانشآموزان با آسيب بينايى تنها در محدوده كلاس درس و مدت زمانى كوتاه مورد بررسى قرار گرفت و فرصت بررسى نتايج بلند مدت حاصل از يزوهش در محيط طبيعى فراهم نشد و در نهايت با توجه به استفاده

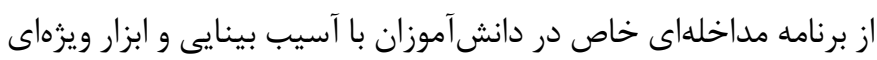
براى ارزيابى مهارتهاى عصب روانشناختى اين دانشآموزان بايد در

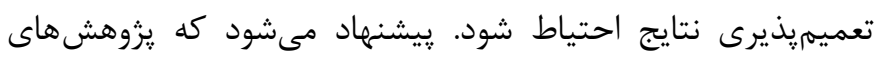
مشابه ديخر با استفاده از نمونههاى بيشترى انجام شوند؛ با توجه به محدوديتهاى طرحهاى تك آزمودنى، طرحهاى گروهى نيز مورد استفاده قرار گيرد؛ روش ها و درمانهاى ديخرى نيز با روش آموزش يردازش حسى مقايسه شوند؛ در كنار ساير روشهاى آموزشى و توانبخى كودكان با آسيب بينايى، روش آموزش يردازش حسى

sual impairment and blind: Psychology, education and rehabilitation. 1st ed. Tehran:Roshd-e Farhang;2016. (Persian)

6. Humphry R. Young children's occupations: Explicating the dynamics of developmental processes. American Journal of Occupational Therapy. 2002;56(2):171-179.

7. Williamson GG, Anzalone ME. Sensory integration and self-regulation in infants and toddlers: helping very young children interact with their environment. Washington:Zero to Three: National Center for Infants, Toddlers and Families;2001. 8. Alizadeh H. Neurocognitive Executive functions and their relationship with developmental disorders. Advances in Cognitive Sciences. 2007;8(4):57-70. (Persian) 
10. Dawson P, Guare R. Executive skills in children and Adolescents: A practical Guide to Assessmentand intervention. 1st ed. New York:Guilford Press;2004. pp. 161-62.

11. Moradi Sh, Mirmahdi S. Effectiveness of working memory and organization method on improvment of function of the students with writing disorder. Journal of Exceptional Education. 2010;3(103):3-11. (Persian)

12. Pourmohamadreza-Tajrishi M, Ashori M, Jalil-Abkenar SS, Behpajooh A. The effectiveness of response inhibition training on the working memory in students with Attention Deficit/Hyperactivity Disorder. Journal of Rehabilitation. 2015;15(4):12-21. (Persian)

13. Hughes C, Graham A. Measuring executive functions in childhood: Problems and solutions?. Child and Adolescent Mental Health. 2002;7(3):131-142.

14. Alizadeh H, Zahedipour M. Executive functions in children with and without developmental coordination disorder. Advances in Cognitive Sciences. 2004;6(3):49-56. (Persian)

15. Welsh MC, Pennington BF. Assessing frontal lobe functioning in children: Views from developmental psychology. Developmental Neuropsychology. 1998;4(3):199-230.

16. Barkley RA, Fischer M, Smallish L, Fletcher K. The persistence of attention-deficit/hyperactivity disorder into young adulthood as a function of reporting source and definition of disorder. Journal of Abnormal Psychology. 2002;111(2):279-289.

17. Haegele JA, Kirk TN, Zhu X. Self-efficacy, executive functions and physical activity among adults with visual impairments. Disability and Health Journal. 2019:1-7.

18. Amel EA, Amira HM. Effectiveness of sensory integration program in motor skills in children with autism. The Egyptian Journal of Medical Human Genetics. 2015;16(4):375-380.

19. Iwanaga R, Honda S, Nakane H, Tanaka K, Toeda H, Tanaka G. Pilot study: Efficacy of sensory integration therapy for Japanese children with high_functioning autism spectrum disorder. Occupational Therapy International. 2014;21(1):4-11.

20. Devlin S, Leader G, Healy O. Comparison of behavioral intervention and sensory-integration therapy in the treatment of self-injurious behavior. Research in Autism Spectrum Disor- ders. 2009;3(1):223-231.

21. Arjmandnia AA, Fathabadi R, Taherian M, Ashori M. The effectiveness of rhythmic movement practices on executive functions of students with intellectual disability. Journal of Empowerment of Exceptional Children. 2017;8(1):68-74. (Persian) 22. Ahmadizadeh Z, Mokhlesin M, Rasolzadeh M, Yaghobi M, Nobarian F. Relationship between sensory processing and motor skills in children with cerebral palsy. Koomesh. 2016;18(2):295-301.

23. Jamshidian E, Jalili N, Haghgoo H. The effect of sensory processing abilities on participation on children with autism. Daneshvar Medicine. 2016;23(120):33-44. (Persian)

24. Arjmandi-Rad Sh, Faramarzi S, Abedi A. Efficacy of sensory integration training on neuropsychological skills of students with attention deficit and hyperactivity disorder. Journal of Research in Behavioural Sciences. 2015;13(4):595-601. (Persian) 25. Motahari-Muyed M, Asgari M, Gharebaghi S. The effectiveness of group-based sensory integration intervention on attention, hyperactivity and impulsivity of elementary students with ADHD. Journal of Clinacal Psychology. 2016;7(3):11-20. (Persian)

26. Nejati V. Comparing executive cognitive functions of brain in blind and matched sighted. Iranian Journal of Military Medicine. 2011;12(4):217-221.

27. Sober SJ, Sabes PN. Flexible strategies for sensory integration during motor planning. Nature Neuroscience. 2005;8(4):490-497.

28. Pfeiffer BA, Koenig K, Kinnealey M, Sheppard M, Henderson L. Effectiveness of sensory integration interventions in children with autism spectrum disorders: A pilot study. American Journal of Occupational Therapy. 2011;65(1):76-85.

29. Hallahan DP, Kauffman JM, Pullen PC. Exceptional learners: An introduction to special education. 12th ed. Boston:Pearson/Allyn \& Bacon;2009.

30. Conners CK, Sitarenios G, Parker JD, Epstein JN. The revised Conners' Parent Rating Scale (CPRS-R): Factor structure, reliability, and criterion validity. Journal of Abnormal Child Psychology. 1998;26(4):257-268. 
31. Ghalamzan SH. Effect of play attention on executive function of children with learning disabilities neuropsychological developmental preschool [MSc Thesis]. Isfahan: University of Isfahan;2011. (Persian)

32. Jenkinson J, Hyde T, Ahmad S. Building blocks for learning, occupational therapy approaches: Practical strategies for the inclusion of special needs in primary school. 1st ed. New Jersy:John Wiley \& Sons;2008.

33. Sonksen PM, Dale N. Visual impairment in infancy: Impact on neurodevelopmental and neurobiological processes. Developmental Medicine \& Child Neurology. 2002;44(11):782-791. 34. Ayres AJ, Robbins J. Sensory integration and the child: Understanding hidden sensory challenges. Los Angeles:Western
Psychological Services;2005.

35. Parham LD, Cohn ES, Spitzer S, Koomar JA. Fidelity in sensory integration intervention research. American Journal of Occupational Therapy. 2007;61(2):216-227.

36. Parham LD, Roley SS, May-Benson TA, Koomar J, BrettGreen B, Burke JP, et al. Development of a fidelity measure for research on the effectiveness of the Ayres Sensory Integration ${ }^{\circledR}$ intervention. American Journal of Occupational Therapy. $2011 ; 65(2): 133-142$.

37. Lang R, O’Reilly M, Healy O, Rispoli M, Lydon H, Streusand $\mathrm{W}$, et al. Sensory integration therapy for autism spectrum disorders: A systematic review. Research in Autism Spectrum Disorders. 2012;6(3):1004-1018. 